\title{
NOTE
}

\section{First record of Emetha audouini, a cymothoid isopod parasite, from cultured sea bass Dicentrarchus labrax in Greece}

\author{
E. P. Papapanagiotou ${ }^{1}$, J.-P. Trilles ${ }^{2, *}$, G. Photis ${ }^{1}$ \\ ${ }^{1}$ Laboratory of Ichthyology and Fish Pathology, Faculty of Veterinary Medicine, Aristotle University of Thessaloniki, \\ 54006 Thessaloniki, Greece \\ ${ }^{2}$ Laboratoire d'Ecophysiologie des Invertébrés, Université de Montpellier II, Sciences et Techniques du Languedoc, CP 092 \\ Place Eugène Bataillon, 34095 Montpellier Cedex 5, France
}

\begin{abstract}
For the first time, Emetha audouini (Milne Edwards, 1840), a cymothoid isopod, is reported parasitising cage cultured sea bass Dicentrarchus labrax L., 1758 in Greece. The specimens observed are larvae (Pulli II). They were found in great numbers in the buccal and branchial cavity of young ( 3.5 mo old) sea bass, in an intensive cage farm facility. This parasite is certainly transferred to sea bass from wild populations of Sparidae or Centracanthidae. Serious lesions were visible and typical of a crustacean infection, with extensive and deep skin damage in the head area. The cumulative mortality, over a $2 \mathrm{wk}$ period, was $10.75 \%$. The parasitic problem was successfully dealt with by optimization of management practices rather than use of costly and dangerous chemotherapeutants.
\end{abstract}

KEY WORDS: Cymothoid - Isopod - Parasite - Emetha audouini Dicentrarchus labrax . Greece

A large population of cymothoid isopods (Crustacea) has been observed on the cultured sea bass Dicentrarchus labrax in Greece. Cymothoids are exclusively parasitic, and the presence of a few adults can cause damage to hosts; this is also the case when a large number of larvae occur. They are protandric hermaphrodites and are blood suckers, living on the skin, in the gill chambers, or in the mouth of the fish.

The parasitic effects include growth retardation, emaciation and, frequently, death of the fish affected. Mortality losses are increased by weight losses resulting from the lowered conditions of the parasitised fish. Usually, the prevalence of infection decreases with fish age and drops to zero in the larger fish. Mucus overproduction has been noted as an accompanying sign in all parasitic diseases (Trilles 1968, 1969, Romestand 1978, 1979, Bragoni et al. 1983, 1984).

Their host specificity varies with the species (Trilles 1968,1969 ). Moreover, a modified specificity is some-

·Addressee for correspondence. E-mail: trilles@univ-montp2.fr times observed following aquacultural procedures (Cassier et al. 1998). In this respect, transfer from mullet to sea bass is possible (Bragoni et al. 1983, 1984), as has been reported for Nerocila orbignyi in Diana pond in Corsica. The occurrence of a large number of Cymothoidae infecting cultured sea bass in Greece represents a new case of modified specificity within the family.

Observations. In November 1997, a serious outbreak of parasitic infection occurred in a cage farm in the Chalkidiki area in Northern Greece, where sea bass and sea bream are reared in adjacent circular cages.

The cage that contained 60000 hatchery-reared, juvenile sea bass of $30 \mathrm{~g}$ mean body weight suffered serious mortalities. The water temperature ranged between 19 and $20^{\circ} \mathrm{C}$, the salinity level of the sea water was 35 PSU and the $\mathrm{pH}$ value was 8 .

According to the description of Trilles $(1968,1972)$, the cymothoid specimens were identified as Emetha audouini larvae (Pulli II) (Figs. 1 \& 2), mainly a parasite of Sparidae and Centracanthidae on the western Mediterranean coasts and never before recovered from sea bass (Trilles 1994).

The most characteristic aspects of this infection were: (1) it was specific to the sea bass (the sea bream Sparus aurata L. cultured in an adjacent cage were not infected); (2) it could have been transmitted by a nearby large population of wild sparids and/or centracanthids. In the affected sea bass the number of the parasites recovered was rather high, averaging 8 to 10 Pulli II per juvenile sea bass.

The prevalence was spread over a 2 wk period, with a resultant cumulative mortality of $10.75 \%$. The clinical signs included loss of condition and death of osmotic stress and possible secondary infections. The infective stage caused necrosis of the gill lamellae. Deep ulcerations, extensive and pronounced haemorrhages, exposure of the musculature of the head and ocular injuries were observed (Figs. 1 to 3 ). 

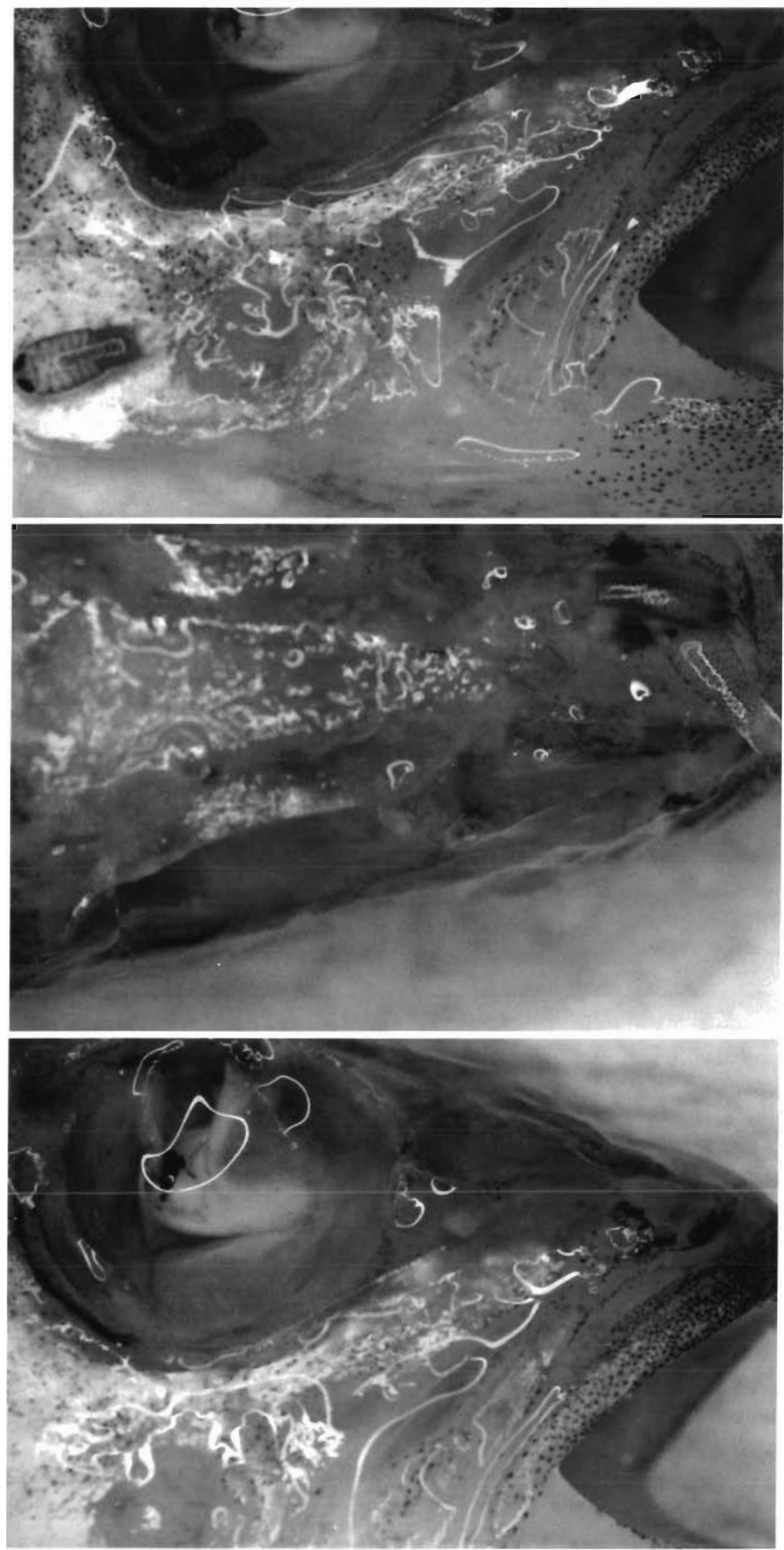

Fig. 1. Two Emetha audouini larvae upon the head of cultured sea bass Dicentrarchus labrax

Fig. 2. Emetha audouini on Dicentrarchus labrax. Deep ulcerations, pronounced haemorrhages and exposure of the musculature of the head of parasitised cultured sea bass; 2 larvae are visible

Fig. 3. Dicentrarchus labrax. The head of a parasitised cultured sea bass with ocular injuries 
Comments. In aquaculture, examples of modified specificity are sometimes observed with some parasites (isopods, copepods, monogeneans); these parasites are never found to be present on the wild populations of hosts whereas the reared individuals of the same species are infected (Raibaut et al. 1980, Euzet \& Raibaut 1985, Cabral \& Raibaut 1987, Cassier et al. 1998). The data from Diana pond for the family Cymothoidae is the only other reported case. The corresponding species, Nerocila orbignyi (GuérinMéneville, 1829-1832), settles on the fins of the fish and moves about easily (Trilles 1968). This parasite enters the pond from the sea with mugilid fishes, which until now were considered its strictly specific host. In the pond, the isopods infect the cultured sea bass.

In Greece, Emetha audouini, mainly a parasite of Sparidae and Centracanthidae, transfers to Dicentrarchus labrax, whose wild populations are never parasitised. This case of specificity, modified and extended, is very interesting since it is the second case observed in the family Cymothoidae and proves the possibility of such parasitic diseases in aquaculture and it is the first case observed involving buccal cymothoids.

Optimal husbandry management (low stocking density, fallowing of sites, farming practices, etc.) should be applied to reduce handling stress and unsuitable conditions that inevitably increase the susceptibility to several pathogens and induce immunosuppression. It is common knowledge in the aquaculture industry that under stressful conditions ubiquitous parasites become major pathogens

The methods that should be applied in the future for prophylaxis of this kind of parasitic problems, which can cause great mortalities and compromise the production of fishes, are immunisation and the selection of resistant individuals via genetic manipulation. Prevention is the best means to control crustacean fish parasites. Crustacean fish parasites are difficult to remove from fish culture facilities. Adult stages of these organisms are generally no more affected by chemical treatments than is the host. Attempts to eliminate the parasites may also damage the host fish. At the present time, fish pathologists can rely on the use of chemotherapeutants, such as organophosphates, hydrogen peroxide, etc., to combat the diseases in the Mediterranean, benefiting from the experience of Northern European countries with sea lice.

However, the experience of Norway and Scotland in the fight against sea lice Caligus elongatus and Lepeophthirius salmonis with the use of hydrogen peroxide, azamethiphos and cypermethrin can only supply crude guidelines for the therapy of crustacean parasitoses in Mediterranean fish farming. That is the case because no toxicity studies for the above chemicals have been performed for sea bass and sea bream. For example, hydrogen peroxide is more toxic at higher temperatures and has only a small safety margin (C. Sommerville, Institute of Aquaculture, University of Stirling, Stirling, UK, pers. comm.).

The transmission of the infection by cymothoid larvae can be prevented by using small-sized mesh nets around the cages (Bragoni et al. 1983, 1984) or filtering the incoming water in land-based tank facilities.

In the present case, no chemotherapeutic agent was applied, and the parasitic disease was manipulated via management practices. The moribund and dead fishes were removed from the cage every day to avoid the recurring infection. The cage was moved away from the shore, into the open sea, where stronger currents, lower temperature and greater depths facilitated the management of the disease. The nets, with adapted meshes, which were fouled, were changed as well.

\section{LITERATURE CITED}

Bragoni G, Romestand B, Trilles JP (1983) Parasitoses à Cymothoadien chez le loup (Dicentrarchus labrax Linnaeus, 1758) en élevage. II. Ecophysiologie parasitaire dans le cas de l'étang de Diana (Haute-Corse). Ann Parasitol Hum Comp 58(6):593-609

Bragoni G, Romestand B, Trilles JP (1984) Parasitoses à Cymothoadien chez le loup Dicentrarchus labrax (Linnaeus, 1758) en élevage. I. Ecologie parasitaire dans le cas d'étang de Diana (Haute-Corse) (Isopoda, Cymothoidae). Crustaceana 47(1):44-51

Cabral P, Raibaut A (1987) Découverte d'un Copépode Caligide nouveau parasite du tégument du loup Dicentrarchus labrax (L., 1758) (Pisces, Moronidae) en élevage et en milieu naturel. Bull Soc Zool Fr 111(1-2):123-130

Cassier P, Brugerolle G, Combes C. Grain J, Raibaut A (1998) Le parasitisme. Un équilibre dynamique. Masson, Paris

Euzet L, Raibaut A (1985) Les maladies parasitaires en pisciculture marine. Symbioses 17:51-68

Raibaut A, Divanach P, Coste F, Maillard C (1980) Copépodose larvaire en écloserie de poissons marins. La Piscicult Fr 61/62:49-51

Romestand B (1978) Etude écophysiologique des parasitoses à Cymothoidae. PhD thesis, University of Montpellier II

Romestand B (1979) Etude écophysiologique des parasitoses à Cymothoadiens. Ann Parasitol Hum Comp 54(4):423-448

Trilles JP (1968) Recherches sur les Isopodes Cymothoidae des còtes françaises. 2nd PhD thesis, University of Montpellier II

Trilles JP (1969) Recherches sur les Isopodes 'Cymothoidae' des côtes françaises. Aperçu général et comparatif sur la bionomie et la sexualité de ces Crustacés. Bull Soc Zool Fr $94(3): 433-445$

Trilles JP (1972) Les Cymothoidae (Isopoda, Flabellifera) des côtes françaises (systématique, faunistique, écologie et répartition géographique). I. Les Ceratothoinae Schioedte et Meinert, 1883. Bull Mus Hist Nat Paris Zool 70: $1191-1230$

Trilles JP (1994) Catalogue mondial des Cymothoidae. Stud Mar 21/22(1-2) (1991):5-288

Submitted: May 4, 1999; Accepted: September 6, 1999

Proofs received from author(s): October 29, 1999 